\title{
Place AND Music: performing 'the region' on the New South Wales Far North Coast
}

\author{
Transforming Cultures eJournal, \\ Vol. 4 No 1, April 2009 \\ http://epress.lib.uts.edu.au/journals/TfC
}

\section{Chris Gibson ${ }^{1}$}

\begin{abstract}
This paper draws on research conducted for over a decade on the musical cultures of the New South Wales Far North Coast, as a contribution to debates in geography and popular music studies on the links between music, place and articulations of cultural identities. Patterns of migration and economic restructuring over the last 20 years have transformed the Far North Coast region, with associated changes in the images conjured to describe the region - from those centred on dairying, fishing and sugar harvesting to those of a 'lifestyle' or 'alternative' region, with growth in employment in tourism, recreational services, 'gourmet' agricultural production, culinary delights, homewares retail and the arts. Music has been a constant presence in the region throughout generations, but became much more pronounced after significant counter-urban migrations to the area began in the 1970s. As music emerged as a unique part of the cultural mix of the region, it became much more diverse, was entangled in local politics, and in the transitions and tensions that have surrounded successive waves of new migrants - both domestic and international - to the region. This article discusses music as a social practice within the region that has played a part in shaping and reflecting evolving regional identities; but at the same time, music constitutes a set of activities that unsettle notions of 'boundedness' or 'stable' associations between place identities and music. I begin with debates about the links between music, place and identity, and the extent to which such associations are performative - constituted in an embodied fashion in the process of describing and enacting certain cultural discourses. Two broad trends are outlined here as 'storylines': one focused on constructions of music as 'authentic' that are linked to place identities, the second emphasises mobility of musical languages, and network metaphors for the repetition of musical practices across locations. Interpretations of musical practices on the Far North Coast hold these storylines in tension; one focused on 'fixing' musical practices in place, the other emphasizing the fluidity of 'the region' in a wider musical geography.
\end{abstract}

\footnotetext{
${ }^{1}$ Chris Gibson is Associate Professor in Human Geography at the University of Wollongong, Australia
} 
This article explores the ways that regional identities and economies shift in interlinked ways - and how music both evokes and actively shapes these transitions. I am particularly interested in the co-constitution of 'the cultural' and 'the economic' and how this co-constitution can be traced geographically (see Gibson 2003a, Gibson and Kong 2005). My perspective is that music does not merely 'reflect' the dynamism of the culture-economy dialectic in the construction of regional identities - as if music, as a form of vernacular culture, was some sort of observable debris left as evidence of regional economic and social change, a 'cultural watermark' created by other more fundamental processes. This view of music - as superorganic form of regional cultural trait or artefact, dominated cultural geography for more than half a century after the Sauerian 'Berkeley school', and is often implied, if not acknowledged, in much cultural studies work on culture and place (see Dunn 2006). Rather, using an understanding of culture informed by post-structuralist approaches to cultural-economy (Amin and Thrift 2007) I would argue that music embodies and constitutes the dynamism of links between economy and culture (see Connell and Gibson 2003). Music is a cultural text capable of being deconstructed for representations of place, identity and transforming economy (Kong 1995, Leyshon et al 1998). But music is more than mere representation (Cohen 1995, Wood et al 2007). Music is a constitutive part of economic and cultural change; it is an industry embedded in places (growing and declining with a mix of microeconomic and demographic factors, which itself contributes to), but also, importantly, as an embodied 'cultural' pursuit through which place identities are performed. By this I mean how music, acting in a more-than-representational way, is central to, and in turn contributes to, the material, embodied, fleshy, emotional, technological and tactile experience of place (Denora 2000, Smith 2004, Duffy et al 2007).

Such a perspective is useful, because it enables researchers to unsettle the static, 'nested' character of geographical scales (local, national, global etc). Geographical scales are semantic categories often problematically assumed to have some extant 'reality' (see Marston 2000). Focusing instead on relations between people, technologies, architectures, physical landscapes and performance acts (whether deliberately 'performative', in the sense of musical performances, or implicitly embodied, as in identity performances) enables observation of how geographical places are constituted and performed in techno-social networks and practices across scales, 
rather than exist a priori, as 'real' Cartesian spaces (Gorman-Murray et al 2008). The 'region' is a revealing geographical construct through which to examine this. What matters are the relational connections between people, technologies, physical landscapes and performance acts, and how these create senses of geographical place and scale rather than seeking to locate an 'authentic' quality or essence in music linked to bounded geographical entities. The 'region' is a geographical construct both commonplace and fluidly employed. 'Region' is a word used to describe areas both large and small, from a sub-national or sub-state area (but usually larger than the local') through to the multinational (e.g. the 'southeast Asian region'). In Australia, the 'region' often, but not always, refers to a sub-state level geographical area containing patchworks of towns, villages, rural and 'wilderness' areas - often conjoined with 'rural' (as in 'rural and regional areas'). There are official boundary definitions for Australian regions in statistical and regional economic discourses (bounded by rivers, catchments, or major conurbations). At other times 'regions' are popularly constructed in media and cultural discourse (from football - the Illawarra Dragons rugby league team - to wine region appellations, as in the 'Margaret River region'). How 'the region' is performed (in the sense described above) is then the focus of this paper. The context is music on the NSW Far North Coast.

After living on the NSW Far North Coast in the late 1990s and interviewing extensively within the region's music industry as part of $\mathrm{PhD}$ research, annual visits over a decade were made possible by coordinating and running an annual field school subject based in the region. I have since built up what is to my knowledge the largest archive of recorded music from the region (several hundred recordings) and media coverage of the region's music (literally thousands of articles over more than 100 years). I have written already on the music scene's history, economic dimensions and relevance to creative industry research (see Gibson 2002, 2003a, 2003b). In this paper I take a different tack. In light of the above discussion, I overtly tease out from past media, from interviews with musicians, as well as from discussions of material cultural practices and specific recordings, a contrasting set of discussions about the music of the 'region'. The paper is organised around two sometimes contradictory, yet not inconsistent storylines. One is focused on music as a means to coalesce the performance of the 'region', as a cultural and economic identity. The second emphasises mobility, and network metaphors for the exogenous linking of regional musical practices to more distant locations. 
Interpretations of regional musical practices on the Far North Coast hold these storylines in tension; one focused on 'fixing' musical practices in 'the region', the other unsettling the idea of a coherent musical 'region', and emphasizing instead fluidity in a wider musical geography.

\section{Storyline 1: performing the region}

This storyline is about the overt performance of place identities in and through music in this case, with particular reference to the 'regional' scale. The emergence of musical activities, the growth of scenes, particular songs, artists or repertoires contribute to and reflect the rise of geographical identities, images and mythologies (Mitchell 1996, Bennett 2000, Connell and Gibson 2003). Regional identities are a particular example of this; they coagulate through music, through attempts to 'fix' musical practices in spaces (whether venues, particular festivals, towns etc) that over time become synonymous with a region. As it has undergone economic and cultural change, shifting ideas about what the region is and what it means to its inhabitants are present in music and the activities that surround music. Patterns of inter-state migration and economic change over the last 20 years have transformed the Far North Coast, with associated changes in the images conjured to describe the region - from those centred on more traditional agricultural pursuits like dairying, fishing and sugar harvesting to those of a 'lifestyle' or 'alternative' region, with growth in employment in tourism, recreational services, 'gourmet' agricultural production, surfing, culinary delights, homewares retail and the arts. The region's more traditional moniker, focused on catchments that provide for the region's historical farm productivity (the 'Northern Rivers region') is increasingly supplanted by a more beach-orientated, tourist-friendly and marketable alternative: Far North Coast. The same revisions of regional identity that have drawn migrants to the area since the 1970s - environmental quality, 'alternative' cultural activities and the arts - have also figured in attracting increased numbers of tourists especially backpackers - solidifying linkages with metropolitan centres and cementing its reputation as an emerging tourist centre with a distinct cultural ambience. The Far North Coast receives approximately 1.8 million domestic visitors annually, and is the second most popular destination in the state behind Sydney for international tourists, with double the number of overseas visitors of any other region (Tourism NSW, 2008). Tourism has become the single most important industry in the region, with tourist 
expenditure alone totalling approximately $\$ 660$ million per annum. Accompanying this has been a shift in local politics: from a staunchly conservative country/National Party heartland the region has become a diverse electorate featuring prominent local Greens members and anti-development coalitions. Aggravating local political conflicts have been differences within the region in urban development orientation (with Tweed Shire Council, for instance, adopting a very pro-development stance compared with neighbouring Byron Shire) and unequal distributions of the benefits of new economic growth. In inland places such as Kyogle, Casino and Grafton, residents have less felt the impacts of revisions in regional identity and economy, even to the point of resenting coastal-focused culture and economic development. Meanwhile, upgrades to the Pacific Highway have made Queensland's Gold Coast only an hour's commute away across the state border. For many, the functional definition of 'the region' - one much more focused on the narrow coastal strip - has expanded to include everyday networks and links with the Gold Coast; for others, there is a heightened sense that the Far North Coast is culturally and physically unique from the Gold Coast (indeed, stands in ideological and aesthetic opposition to it), and ought to be protected from further 'Gold Coast style development'.

Music has been woven throughout this economic, social and political transformation, evident when tracing a brief history of the region's music. In earlier periods of the $20^{\text {th }}$ century, when the region was reliant on dairy and sugar cane farming, and physically remote via road and rail infrastructure from capital cities, community dance halls made up the bulk of public musical spaces in the region. Pubs closed early, and community and special purpose halls (such as bowling clubs) were the sites of community music, from old-time sequenced dancing, country music sing-a-longs and swing bands to Hawaiian and Polynesian nights. Country music was also heard throughout the region at annual town shows, community festivals (such as Grafton's long-running Jacaranda Festival) and rodeos. Country music nights continued in local sporting and cultural clubs, especially in inland towns, even when the region underwent the later demographic and cultural transformations of the 1980s and 1990s - one such night was the as yet unparalleled residency of over twenty years carried out by the Country Gentlemen at Woodburn-Evans Head RSL Club. A country music touring and broadcasting network, operating throughout the wheat-sheep belt of agricultural production in New South Wales and Queensland, incorporated pub venues, rodeo balls 
and festivals in the Far North Coast region (many of which still remain a part of the Australian country music scene).

Although these vernacular musical activities were embedded in the region, other than rodeos and shows, before the late 1970s there were very few, if any, tours to the region by visiting high profile recording artists, and few established infrastructures for live performance other than community dance halls and later RSL (Returned Services League) and bowling clubs. In the late 1970s and early 1980s, as the region was integrated into domestic and international tourism industries, and as counter-cultural and 'sea change' migration accelerated, the region began to be integrated into a nascent East Coast live music network. Tours increased by Australian bands such as The Angels, Cold Chisel, INXS and The Reels (all at early stages of their careers), appealing to the region's large working class population and, in summer months, increasing numbers of tourists from urban areas. Improved highways, cheap motels and the advent of the tour bus made tours with multiple stops in coastal towns possible. The growth in coastal beachside holidays and popularity of towns such as Coffs Harbour, Ballina, Tweed Heads and Byron Bay also produced a ready-made market for live music, and accordingly, the region became part of a live music management network covering the holiday coast between Brisbane and Sydney. One promoter interviewed for this research described in particular detail how since the 1980s a refined geography of coastal touring had emerged and became controlled by a small number of promoters: his 'territory' covered specific rock venues in certain towns and was 'protected' through unwritten agreements with other promoters (whose territories abutted his). Within his territory spanning a particular network of pubs from just north of Coffs Harbour to the Queensland border - he enjoyed a monopoly over booking metropolitan touring acts. Another similar network takes in several of the highest profile live music venues in the region - the major pubs in Byron Bay, Nimbin, Bangalow and Murwillumbah - all owned by a single publican, and managed by booking company Byron Bay Entertainment. In this way, in just the 'pub rock' scene, a particular networked geography of the region's live music spaces is performed and controlled.

In the late $1970 \mathrm{~s}$, as economic and demographic change accelerated, a range of new smaller venues, especially in pubs, began to put on local bands, and held disco nights, and more international artists began to be booked at larger venues such as Lismore City 
Hall. Local advertisements for these events demonstrate the extent to which music from elsewhere was perceived to have (finally) arrived in the region, paralleling the 'discovery' of the region by in-migrating hippies, surfies and students. Thus, the Commercial Hotel advertised that the 'disco scene explodes in Casino', while a 1977 tour of Country Joe and Kevin Coyne was presented by Live Coverage tour promoters, with almost a sense of surprise, 'in Lismore (of all places)'.

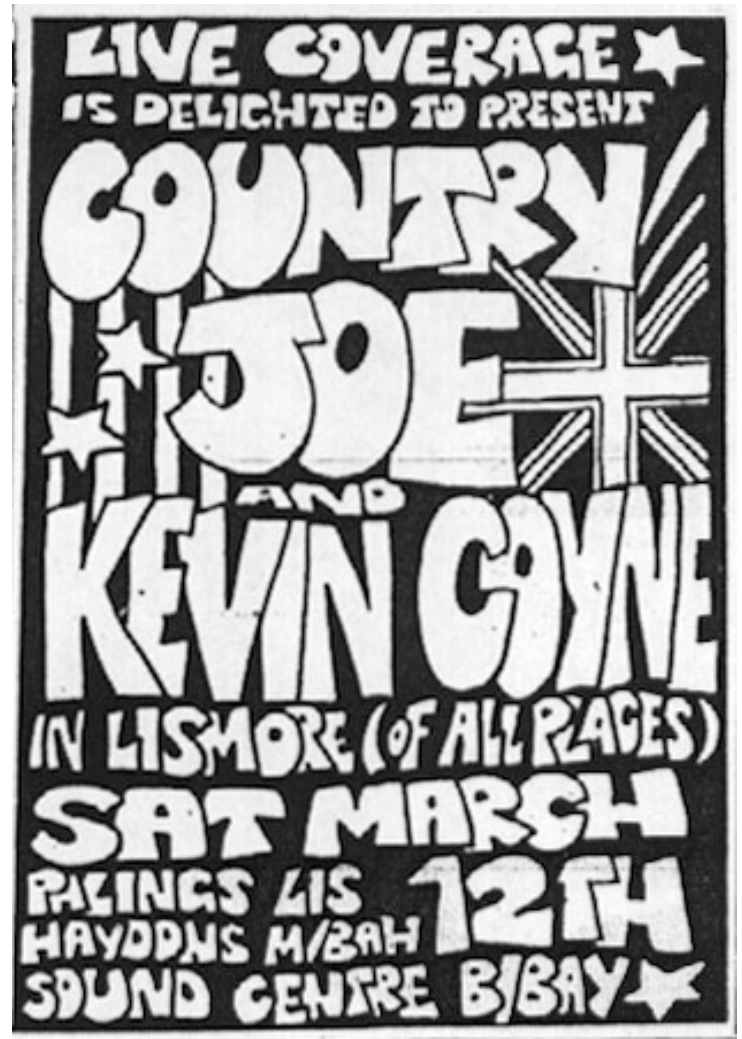

International music 'arrives' in Lismore, The Northern Star, 26/2/1977:11

Similarly, A 1980s review of Cold Chisel's first tour of the region claimed that 'the band had enjoyed its first Lismore concert and was impressed with the extent of acceptance its music has found in a rural area of limited population' (The Northern Star, 1980:27). This was certainly surprising, given that Don Walker, songwriter and keyboardist with Cold Chisel, grew up in nearby Grafton. Around this time, recording studios were established in Nimbin (Bush Traks) and in the hills outside Byron Bay (The Music Farm), bringing music production as a new cultural industry (Gibson 2002). Early rock bands playing in the region played covers (such as Hoodwink, Aleph, Vacant Lot, Bourbon Street and Rockola), and a few local rock and punk groups recorded original material (such as Giant Steps and The Strap Ons). Again, a particular 
configuration of bands, venues, releases and musical texts mapped out figuratively and literally the shifting contours of the region's cultural and economic change.

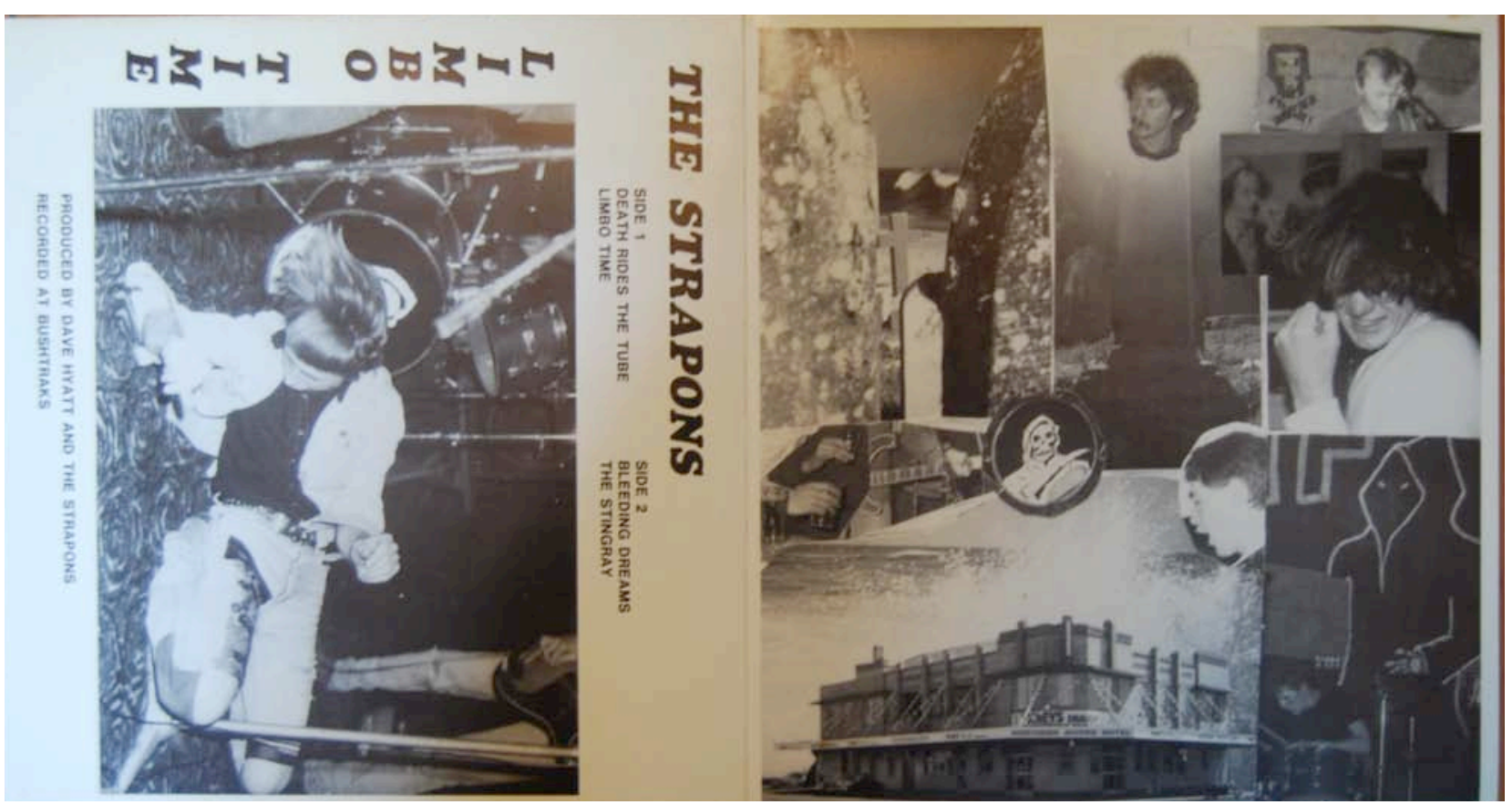

Gatefold sleeve cover to The Strap Ons, Limbo Time (c1985), 7" record, EMI Custom Records (Note the cover photographs of pub gigs in the region, and a shot of an iconic Lismore live venue, the Northern Rivers Hotel)

A catalytic moment for folk musicians and those of 'alternative' political persuasions was the Aquarius Festival in Nimbin in 1973, the first major 'hippie' festival in Australia, which attracted musicians, artists and students to the area (Hannan 2000, 2002). Billed as Australia's answer to Woodstock, Aquarius was actually focused primarily on politics and the establishment of alternative ways of living. Albeit very informal and small-scale, music certainly was an important part of the festival. Information on the music presented at the festival is sketchy, but among the musicians known to have been involved in the Festival were singer Paul Joseph (a former cast member of Jesus Christ Superstar); Donny McCormack (ex-Nutwood Rug Band); Indian ensemble Bauls of Bengal; folk-anarchist Neil Pike (who would become a pivotal figure in the Nimbin music scene for the next thirty years); and The Larrikins, from whom band member Jacko Kevins remained in Nimbin after the festival and became a founder member of the Tuntable Falls intentional community.

More than a mere music festival, Aquarius 'saved' what was effectively a dying dairy village from becoming 'a ghost town' (Hannan 2002:3), and set in train a momentum 
building behind the region's reputation as an 'alternative' mecca. Due to both its spectacular surrounding landscapes and available physical structures (previously used by the centralising dairy industry), inland Nimbin and Byron Bay on the coast became havens for city-dwellers seeking refuge; through the 1980s and 1990s the region saw some of the highest rates of population growth in Australia, attracting a myriad of subcultures, migrants, retirees, students, the unemployed and travellers to its natural and cultural environment. Music was more than a mere mirror to this trend: Byron's growing reputation as a music mecca during the 1980s was a major drawcard for 'alternative' tourists and in-migrants in the cultural and creative industries; the presence of recording studios (culminating in the decision in 2003 by the School of Audio Engineering (SAE) to base its global headquarters in Byron Bay), expanding live music venues, and Southern Cross University's new music degree (based in Lismore) all made the region a legitimate place to move to in order to pursue careers in the cultural industries (Gibson 2008).

Diversity now defines the region - and its music scenes. Unlike in other places, where place identity and music are seen to be linked by a common style, genre-affiliation or 'sound' (Gill 1993, McLeay 1994, Mitchell 1997), on the Far North Coast there is no unifying regional 'sound'. However, within certain musical communities such claims are frequently made, as bands and commentators seek to 'fix' regional identities in musicological practices. For example, surrounding Southern Cross University's music degree is a discernible jazz/funk scene (in part influenced by the strengths of teachers in that degree); while following in the wake of Grinspoon's national success as a majorlabel band, the muscular hard rock sound was also said by many band members to characterise Lismore; contrasting this is an emphasis on 'ethnic' and 'global' styles at Byron Bay, especially reggae and ensemble percussion sounds (see below). All these claims jostle for discursive space in the region's musical landscape.

If then, there is not a single significant, musicologically-distinctive 'sound' on the Far North Coast, regional identities are certainly buttressed through material musical practices such as live performance, choice of venues, and methods of recording, production, marketing and touring. 
Some of the region's music production and live performance is explicitly geared to tourists, and through this, the region is deliberately packaged and marketed in certain ways. Live venues in Byron Bay such as the Beach Hotel hire reggae bands, touring world music acts and 'alternative' cover bands on Friday and Saturday nights to play to very large crowds (upwards of 1500) of mostly (though not exclusively) tourists. Recorded releases by David Birch (Byron Journey, 1997), and the prolific Tarshito, who has to date released over 40 full length $\mathrm{CDs}$ and cassettes in the new age/ethnic/world beat genres, play on imagery and tourism marketing synonymous with the region. Depictions of local beaches, ocean scenes, rainbows and dolphins are prioritized over the more radical or crusty images of the region's folk, blues and techno scenes. These are images that also dominate official tourist promotions for the region, branded as 'Sub-tropical NSW' and 'The Rainbow Region': beaches, sunsets, rainbows, volcanic mountain scenery. Adding a more embodied dimension to the music-tourism interface in Byron is the presence of percussion groups, folk musicians and blues groups as buskers on its main streets - especially during summer months. In strategically targeting tourists as captive market, buskers and hired bands alike perform 'tourist Byron' (especially emphasizing percussion, 'world' music blends, and didjeridus), and bolster its reputation as 'backpacker central' through music (Gibson and Connell 2003).

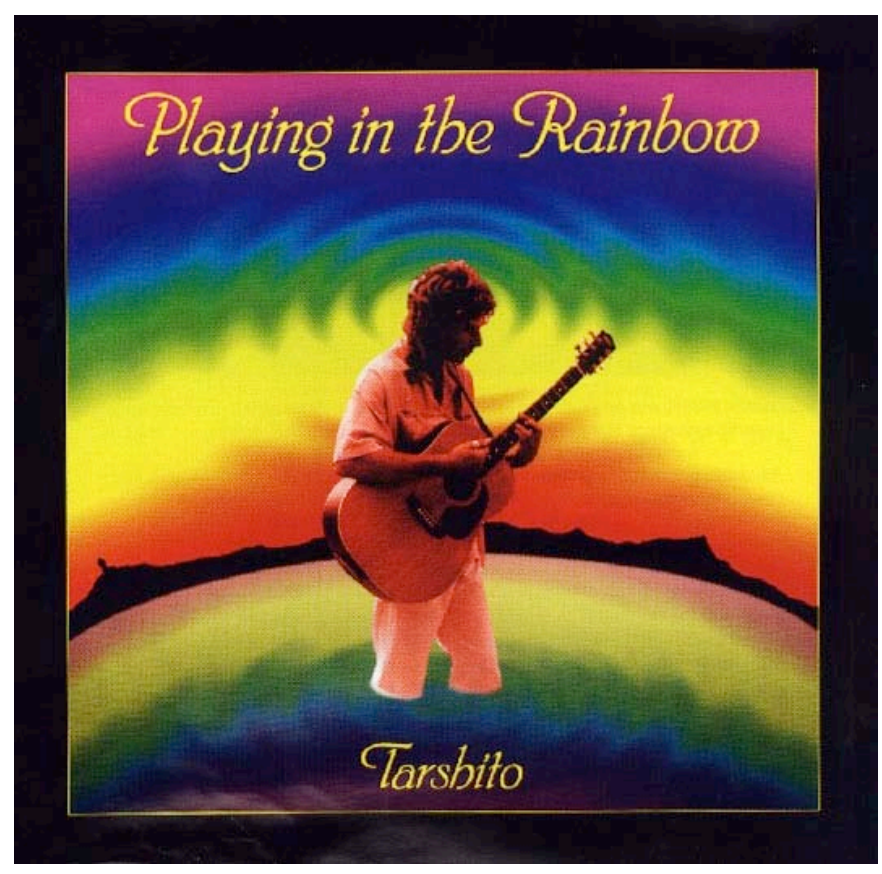

Tarshito, Playing in the Rainbow (1994), CD, Kittani Music (note scenic backdrop to the cover, depicting the silhouetted landscape view from Byron Bay's main beach) 
Much less connected to tourism audiences, musical practices contribute to a generic, though often place-embedded, discourse of 'alternative economy' that many see as synonymous with the region (alongside other informal sector activities (market stalls, arts and crafts, drug trade). An example is the DIY scene surrounding thrash metal label Green Tent, active in the late 1990s and early 2000s, who released a series of recordings by bands such as Soy Division, The Lame-Os and Verbal Abuse, using basic technology, hand-drawn art and photocopied covers, and coordinated the music/pop culture 'zine Up Tha Duff. In this case, the deliberately analogue, 'lo-fi' production and aesthetic performs the region, as a musically and culturally left-of-centre, 'feral' place. Their sardonic slogan 'Lismorons doing it for themselves' emphasizes independence and grass-roots collectivism, consistent with the more general ethos of local culturaleconomy and anti-corporate resistance in the region. With the more recent advent of computer-based recording and mastering technology, the DIY rhetoric has expanded significantly across genres, including indie rock (bands such as Very Unique Existence, from Byron Bay) and reggae (Positive Timing, The Lion I Band). While computerbased self-production now characterises music scenes pretty much everywhere, in this region it especially accrues meaning because of the region's strong independent, 'alternative' ethos.
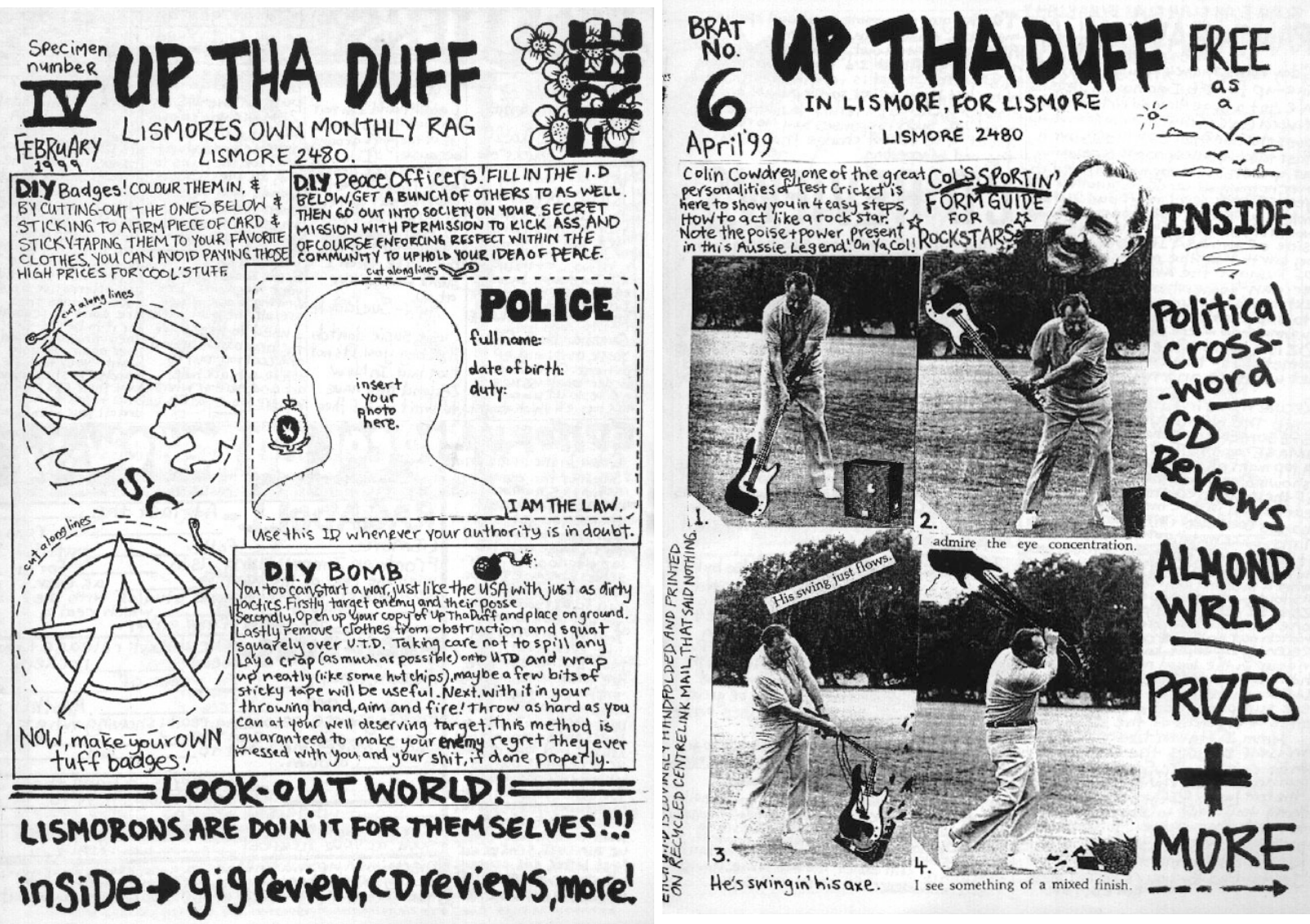

Up Tha Duff 'zines, Lismore, 1999 
Another example in this storyline of 'performing the region' involves particular architectural spaces: the phenomenon of the 'hall gig'. Community halls, the main venues for square dancing and country music sing-a-longs during the first half of the $20^{\text {th }}$ century, were first revitalised by folk and blues musicians in the $1970 \mathrm{~s}$, as rock and folk performance spaces. Few pub and club venues would at that time put on original music by hippies (who smoked dope rather than consume large amounts of alcohol), preferring rock bands. The rural location of the halls (cheap to hire and a long way from police and complaining residents) enabled a setting that matched the pastoral and rustic aesthetic characterising much of the music played there. Popular nights included performances by regular local acts such as Fly By Night, Aleph, High Beam, Bahloo and Troppo; occasional touring international acts such as Robin Williamson, formerly of the Incredible String Band; and monthly moon dances and full moon parties. As Barry Ferrier recalled:

There was a good scene in the country halls around here. That was great independently run dances where the band would put on a dance, sell grog and food. They were pretty wild. The police wouldn't really bother you cause they were way up in the hills. It was quite a golden era of music around here in that scene.

Bahloo were one of the earlier groups from this scene to gain recognition - their 1984 album Living on an Island, recorded at the newly established Music Farm recording studio in the hills inland from Byron Bay, secured national distribution through EMI on LP and cassette. Listening to this album 25 years later, it clearly captures the experimental, hybrid and optimistic nature of the region's cultural outlook at the time acoustic instruments were combined with electric pianos, moog synthesizers, rock and reggae influences. Lyrics spanned a range of concerns, from upbeat songs intended to get crowds to dance and sing along, through to anti-uranium mining and nuclear war anthems - critical takes on the over-development and rapacious industrial greed of the cities that many counter-cultural migrants had sought to escape by moving to the region. 

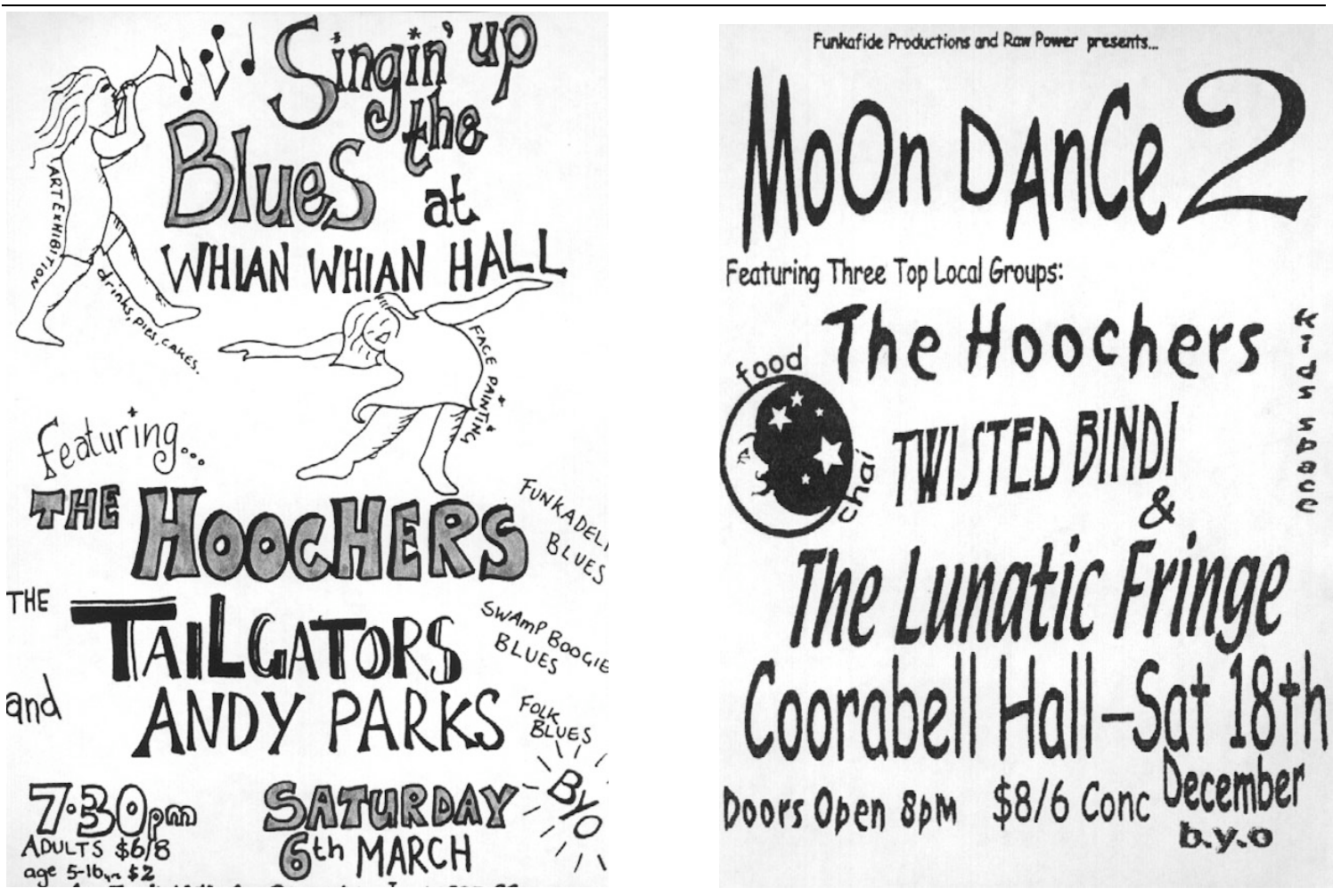

Featuring Three Top Local Groups:

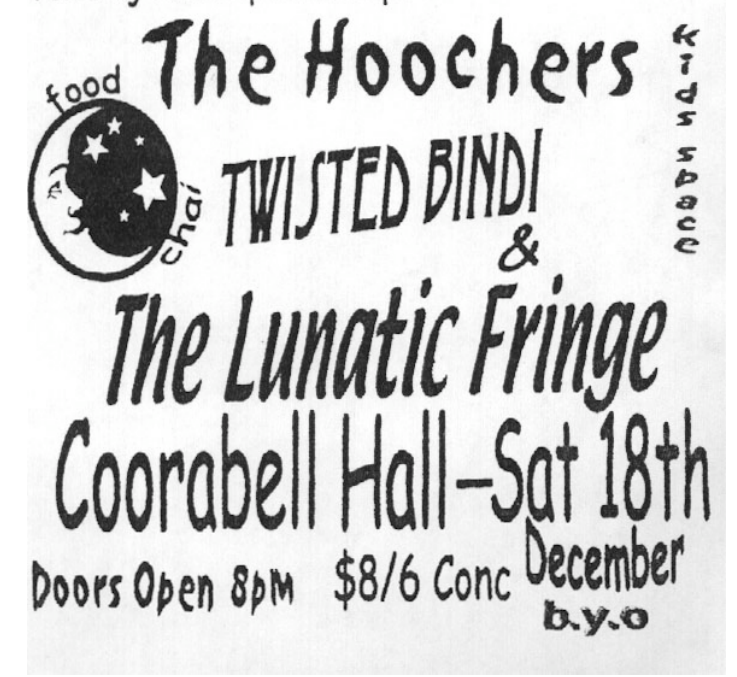

Hall gig flyers, Whian Whian Hall and Coorabell Hall

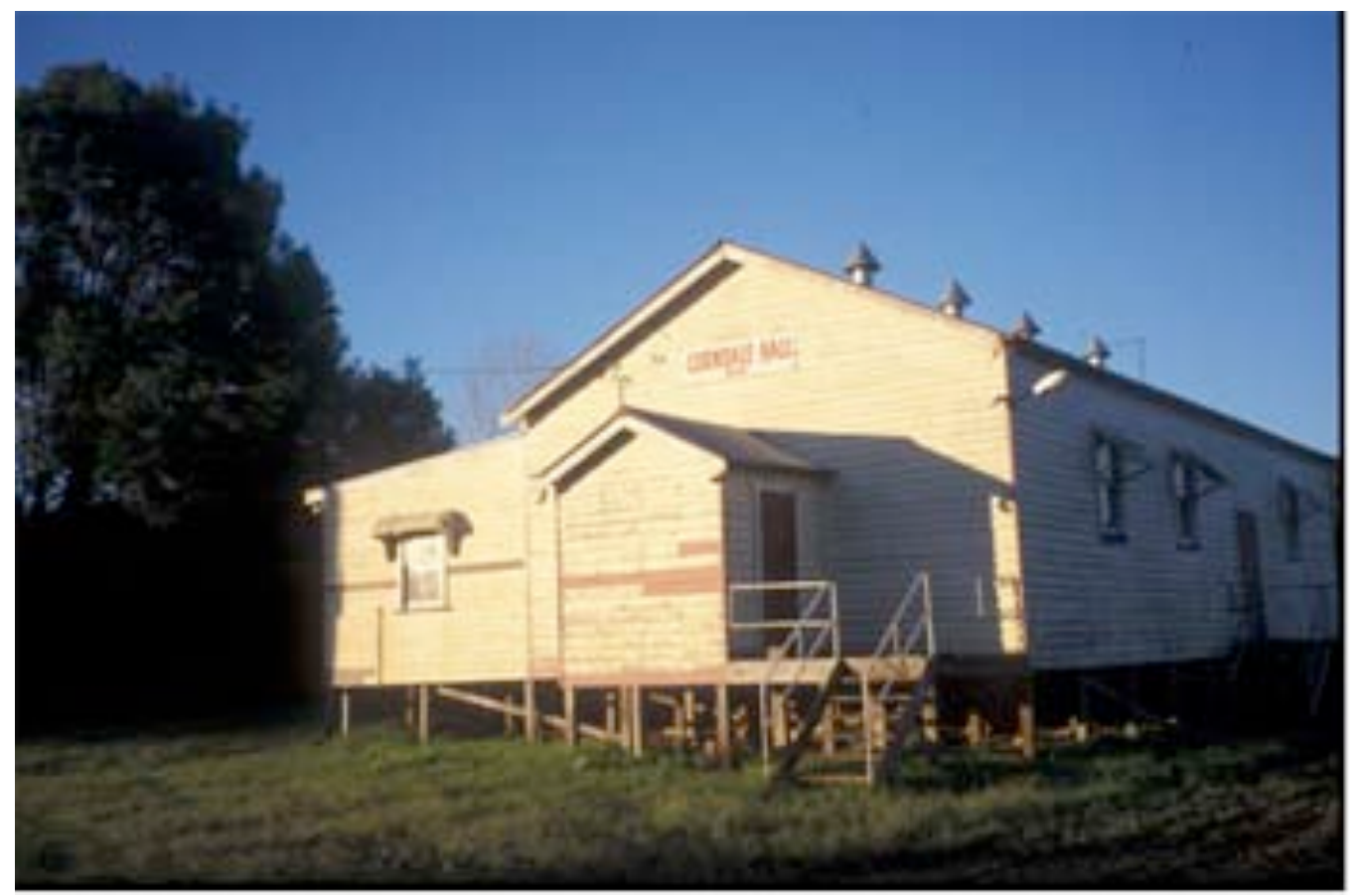

Corndale Hall, 2003 (Photo C. Gibson)

Pertinent here is that since the late 1990s there has been a second renaissance in the community hall as a space for performance, in reaction to a loss of venues in the region blamed on poker machines and greedy publicans. Village dance halls, in places such as Coorabell, Corndale, Whian Whian and Broken Head, have been transformed once 
again into spaces for doof trance techno parties, folk and blues nights and full moon raves. These are almost exclusively informal events, and tend to have an emphasis on community participation and support, word-of-mouth and flyer advertising, and a decidedly non-commercial intent. Hall gigs are usually alcohol free, with the nonsanctioned use of marijuana and other psychedelic drugs. As Andy Parks, singersongwriter with Lismore group The Lunatic Fringe and owner of the web-label Raw Power Productions described,

the thing that I've got into over the last couple of years is hall gigs, I don't really like playing in pubs, so there's a great selection of halls here, in the hills - the Repentance Creek Hall is a good one, Corndale Hall, Coorabell Hall - that's great. I played a gig last weekend at Whian Whian Hall, and it's the same. You put a deposit on the hall, you pay maybe eighty bucks hall hire, get a PA, get a few bands together, and do it all yourselves.

Ragadoll, a band strongly associated with the 'hall gigs', mythologized this scene in music, depicting it in album cover artwork and in song. Their 1998 CD The Psychotic Dance Hall Call featured artwork by Jimmy Willing, the band's lead singer, including images of various aspects of suitably rustic country-folk-roots entertainment, from antiquated farm equipment to images of travelling troupes of musicians, puppet shows, and pictures of gypsy carvings. Sonically, the album included stomping acoustic jams, harmonica blues romps and tales of wild abandon; Ragadoll emphasised folk roots, precapitalist modes of production, and traditions of wandering bush entertainers. The lyrics to the title track, 'The Psychotic Dance Hall Call' evoked the dance hall scene:

I had become the Psychotic Dance Hall Caller and every time I played my harmonica it was so loud that hallucinations jumped from the floorboards and danced around my feet. The wilder I played, the wilder the dancers danced the dance... at that moment the dance hall, this surreal parade, this painted pageant masquerade, seemed a crazy magic toy shop that I controlled with music (The Psychotic Dance Hall Call, 1998).

A particular version of the region - focused on earthy entertainment, appeals to roots, alternative culture, marijuana (and acid) consumption and a particular architectural space, the community dance hall - was thus created, and literally, performed.

More recently, and again reflecting cultural-economic divisions in the region, local controversy erupted over music in Coorabell Hall - one of the key hall venues. Noise complaints from nearby neighbours in April 2008 led the Hall's organising committee 
(populated at that time by members of long-term Coorabell farming families) to ban live music (Byron Shire Echo 2008). In response, a coordinated and active 'save the music' campaign was launched, and a management plan drafted to manage noise. The ban was lifted later in the year after noise management plans were accepted on a trial basis, and a 'gracious' change in personnel for the Hall committee took place (with a new, pro-live music lobby elected unopposed). What was once a highly informal - even radical - site of musical expression, beyond surveillance and regulation, had become a formally accepted, and managed, aspect of the local musical landscape.

\section{Storyline II: the region and exogenous relations}

If my first storyline focused on the coalescing and performance of 'the region' through discursive as well as material musical practices, a parallel, if contradictory, geographical storyline threads through the Far North Coast's music regarding relations with outside, exogenous places. This is a storyline in part about hybridising and replicating outside influences, a 'pluralism of musical languages repeat[ing] itself from one community to another' (Straw 1991: 378) and the 'glocalisation' of styles (Mitchell 1996). An example of this is how 'world music' styles have become popular in Byron Bay. As Byron developed wholefood and vegetarian eateries, craft shops, yogic dance, and naturopathic therapies, much of the music produced and performed there also sought to appropriate and adapt elements of a cosmopolitan alternativism, deliberately 'global' in its aspirations (Gibson and Connell 2003). Links to world music are overt, and thus debates about world music's Orientalism, exoticism and 'otherness' are relevant here (Garafalo 1993, Feld 1994, Taylor 1997, Connell and Gibson 2004). Much of the music produced in this scene, focused on Byron Bay, relies on appropriating elements of non-western musical forms within a more orthodox western musical context, such as the incorporation of Latin, Asian and African instruments within western conventions of harmony, rhythm and arrangement. A diversity of cultural influences is a premium: reggae-world outfit Positive Timing describe themselves as 'a multi-cultural collective of passionate musicians from France, Colombia, Mexico, America, Malta and Australia, creating a worldly flavour of music which appeals to a wide audience' (Positive Timing 2008); Los Bobos Cosmicos were described in one local magazine as 'African township jive, skanking reggae, Latin American percussion, Western rock guitar and pop vocals, with some Middle Eastern snake charmer-type 
saxophone sounds thrown in for good measure'; while the album World CitiZen (2005), by Yeshe Mbira, a self-described 'world nomad' now based in Byron Bay, was described as

Threading the colours of mbira and the Shona spirit through a texture that recalls flamenco and Spanish echoes, didgeridoo, conga and even blues guitar, Yeshe brings together diverse cultures and music with striking compatibility and resonance' (Turner 2005).

Flyers, CD Covers and website designs for musicians, releases and events emphasised their global significance, while maintaining connections to a whole range of such symbols: Celtic designs, Indian gods, otherworldly images and psychedelic artwork, along with more localised images familiar within Australian tourism campaigns (Waitt 1997, 1999), including native fauna and Aboriginal designs: promises of wilderness and primitivism for potential backpacker customers.

Beyond genre, musicological and representational concerns, there are also particular forms of 'network sociality' (Wittel 2001) that stretch material musical practices beyond the region, connecting musicians, audiences, technologies and touring opportunities. Regional music production, live performance and scene-building all require contextualizing in the wider industry and translocal technological architectures for popular music production and distribution. Through these, a contrasting geography of the region's music is performed.

At the same time that the community hall scene and DIY labels have emphasized localism and grass-roots resistance to corporatisation, the region has also been intermittently incorporated into the various mechanisms established by the international music industry for recording, distributing and performing music. Recording artists from the region with national and international careers include Grinspoon, Diana Ah Naid (from Nimbin), the Simpletons, Don Walker and multiple golden-guitar winner Troy Cassar-Daley (from Grafton). Following Grinspoon's rise to fame, a swag of new hard rock bands emerged, particularly from Lismore - including Seven, Chen Lab, Headlifter, Khaki Marquee, Defect, Spirit, Spesomen, and Chilblain - releasing their own professionally-recorded material (often self-financed, at great expense), signing management deals with promoters, and quickly seeking gigs in Sydney. While the region might be a conducive place to become a musician (with its alternative culture, 
student population, backpacker market and drug scene), like Grinspoon before them, for these bands the radar was clearly targeted on moving beyond the region, securing a recording contract and moving on to bigger cities and deals. Seven were picked up by Australia's major booking agency, Harbour; Headlifter signed a distribution deal with MGM and relocated to Sydney; as did both Diana Ah Naid and Troy Cassar-Daley after signing to major corporate labels; while Defect made a music video played on ABC's weekend music television show, Rage. Use of MySpace and other social networking websites has also become commonplace, and on these what appears to matter most is airplay on Triple J, and tours to Sydney and Brisbane. Sometimes artists have sung about the Far North Coast region (as in Cassar-Daley's 'Big River' and the Simpletons' somewhat disparaging 'Ode to a Town', about Lismore), but such geographicallyspecific themes are infrequent. Taking precedence in this storyline of the region's music are connections made by performers to labels, opportunities and audiences elsewhere.

A flip-side to this has been the incorporation of the region into national and international touring networks for live music, often by music promoters piggy-backing on Byron Bay's status as 'backpacker town with 'cred'. Long-gone are the days of the local press exclaiming surprise that a touring international act would actually play anywhere in the region. Byron's premiere rock music venue, the Backroom at the Great Northern, is now part of a touring circuit including major capital city venues, and touring artists frequently add Byron Bay to their short tour list as the only gig in Australia outside a capital city (as did Bob Dylan recently). The East Coast Blues and Roots Festival, and annual indie rock festival Splendour in the Grass, established in 1989 and 1991 respectively, have both confirmed the region's status in international touring networks.

The presence of SAE in Byron Bay since 2003 has cemented this much more globalised, networked performance of the region's music, in terms of training both local and international students in professional audio and video recording and production. Students from North America and Europe, attracted to Byron's cultural and environmental amenities, have returned after graduating at SAE to win international awards and work in the music and film industries, maintaining international professional links with Byron; while domestic students trained at SAE gain work regularly in the larger music, film and advertising industry centres of Sydney, 
Melbourne and Brisbane. This flow-through of students, and the subsequent professional networks established by them after graduating, have normalised Byron Bay as a centre of technical education within a broader geography of music production.

Somewhat parallel to this, but on a more grass-roots scale, has been the incorporation of the region into international networks of production, distribution and performance in specific niches, and especially electronic, techno/trance and dub genres. Backpackers provide a ready market for DJ nights - at Byron's La La Land nightclub in particular, because backpackers rarely venture into the hills for hall gigs - while the drug reputation of the region fuses with the dub and trance/techno scenes. So much has this been the case that Byron Bay has become one of the most important sites in Australia for the psy-trance sub-genre. A slew of legal and illegal dance parties have been staged in Byron Bay and its surrounding hills for over a decade, by both local organisers and ex-Sydneysiders who fled in response to police crackdowns on free parties in inner-city parks in 1995. Producers in the region established independent trance and dub electronica labels including Edgecore, Organarchy, Silicon Buddha, Dubshack and Digital Psionics; while local community radio station Bay FM started regular trance shows. Crucial to the maintenance of trance scenes on the Far North Coast has been a heightened sense of its place in a global matrix of subcultural consumption - as travellers brought back stories of local dance parties, as subcultural press (such as the UK's Mixmag dance magazine) wrote up Byron Bay as a major world venue for raves and dance parties, and as international producers and DJs were drawn to the region. Conversely, for techno producers, economic survival relied on internationalizing distribution channels, including through internet ordering and heavy use of email between event producers, artists, label directors and DJs. For Paul Chambers, promoter, musician and DJ with the Edgecore label:

We're not going to make it just locally; we're very careful not to just concentrate on even Australia... you've got to have a global point of view, a global outlook, and we're out to try and do well, trying to make it very professional, a quality sound, and on a world scale. That's what we aspire to.

Rather than claim any link to the region, Edgecore releases feature music produced by psy-trance artists from Eastern Europe, Israel, North America and across Australia. The region of course did matter at one level - its production infrastructure, links to tourist audiences and ethos of alternativism supported the growth of a regional dance/trance 
music scene - but simultaneously Byron Bay had by this time also come to occupy an iconic set of coordinates in global dance music networks. 'The region' came to occupy another position, in a more transnational, material geography of production and distribution.

Now more fully networked into national and international circuits of production, education, music distribution and touring, the musical landscape of the Far North Coast has come to encompass the full spectrum of styles found in any major metropolitan centre. Even within electronic dance music scenes there are multiple variations and fragments, with lounge nights, breakbeat DJs, house parties, underground doofs, the ever-present trance scene, not to mention the popularity of hip hop, funk, 'new age', dub reggae, 'world' music and jazz in the region. Supplementing musical activities and identity performances that emphasise the region and its 'alternative' cultural ambience are a more diffuse set of economic, technological and subcultural networks linking the region to wider cultural geographies of music.

I have sought to show here the different ways in which 'the region' is performed in music. In a most immediate sense, the region is performed through the material practices of making music, performing, recording and touring within and from this region. Across different scenes - from grass-roots folk to thrash metal and psy-trance the region is performed musically. This is a textual, representational phenomenon - in songs, in lyrics, in cover art, in representations of regional identities and in claims to regional musical aesthetics. But more so, the region is performed in an embodied, nonrepresentational manner by musicians, as venues are made culturally meaningful spaces through live performance; as a sense of the region as touring territory is carved out (and protected) by promoters; as DIY production embodies regional preferences for 'alternative' cultural-economy, as architectural spaces such as community halls are made sites of musical activity and meaning. There is no 'regional music' of the Far North Coast, no single regional 'sound'; but there is an active set of technological, social and economic networks through which regional music is performed, 'fixed' in relational space, and yet always made geographically fluid.

\section{Bibliography}

Amin, Ash and Thrift, Nigel (2007) "Cultural-economy and cities", Progress in Human Geography, 31(2): 143-161. 
Bennett, Andy (2000) Popular Music and Youth Culture: Music, Identity and Place. Basingstoke: Macmillan.

Byron Shire Echo (2008) "Coorabell music lobby triumphs", Byron Shire Echo, 29 July 2008, p. 4

Cohen, Sara (1995) "Sounding out the city: music and the sensuous production of place", Transactions: Institute of British Geographers, 20: 434-446.

Connell, John and Gibson, Chris (2003) Sound Tracks: Popular Music, Identity and Place. London and New York: Routledge.

(2004) "World Music: deterritorialising place and identity", Progress in Human Geography, 28(3): 342-361

Denora, Tia (2000) Music in Everyday Life. Cambridge: Cambridge University Press.

Duffy, Michelle, Waitt, Gordon and Gibson, Chris (2007) “'Get into the groove': the role of sound in creating a sense of belonging in street parades", Altitude, 8 $<$ http://www.altitude21c.com/>

Dunn, Kevin (2006) "A comparative genealogy on place: cultural geography and cultural studies", Geographical Research, 44(4): 423-426.

Feld, Stephen (1994) "From Schizophonia to Schismogenesis: on the discourses and commodification processes of 'world music' and 'world beat", in Stephen Feld and Keil, Charles (eds.) Music Grooves, Chicago: Chicago University Press, pp. 257-289.

Garofalo, Rebe (1993) "Whose world, what beat: the transnational music industry, identity and cultural imperialism", The World of Music, 35: 16-32.

Gibson, Chris (2002) "Rural transformation and cultural industries: popular music on the New South Wales Far North Coast", Australian Geographical Studies, 40(3): 336-356.

(2003a) "Cultures at work: why 'culture' matters in research on the 'cultural' industries", Social and Cultural Geography, 4(2): 201-215.

(2003b) "Rainbow sounds: musical cultures of the Far North Coast", in Helen Wilson (ed.) Belonging in the Rainbow Region: Cultural Perspectives on the North Coast of NSW, Lismore: Southern Cross University Press, pp. 263-286.

(2008) "Youthful creativity in regional Australia: panacea for unemployment and out-migration?”, Geographical Research, 46(2): 183-195.

Gibson, Chris and Connell, J (2003) "Bongo Fury: tourism, music and cultural economy at Byron Bay, Australia", Tijdschrift voor Economische en Sociale Geografie (Journal of Economic and Social Geography), 94(2): 164-187.

Gibson, Chris and Kong, Lily (2005) "Cultural economy: a critical review", Progress in Human Geography, 29(5): 541-561.

Gill, Warren (1993) "Region, agency, and popular music: the Northwest sound 19581966", The Canadian Geographer, 37(2): 120-131.

Gorman-Murray, Andrew, Darian-Smith, Kate and Gibson, Chris (2008) "Scaling the rural: reflections on rural cultural studies", Australian Humanities Review, 45: 3752

Hannan, Michael (2000) "Musical practices and cultural identity in the village of Nimbin", in Tony Mitchell, Peter Doyle and Bruce Johnson (eds.) Changing 
Sounds: New Directions and Configurations in Popular Music. Sydney: University of Technology, pp. 42-46.

(2002) "Music making in the village of Nimbin". Transformations, 2, $<$ http://www.ahs.cqu.edu.au/transformations/journal/pdf/no2/hannan.pdf $>$ (accessed May 3, 2008)

Kong, Lily (1995) "Popular music in geographical analyses", Progress in Human Geography, 19: 183-98.

Leyshon, Andy, Matless, David and Revill, George (eds) (1998) The Place of Music. New York: Guilford Press.

Marston, Sally (2000) "The social construction of scale", Progress in Human Geography 24: 219-242.

McLeay, Colin (1994) “The 'Dunedin Sound' - New Zealand Rock and Cultural Geography", Perfect Beat, 2(1): 38-50.

Mitchell, Tony (1996) Popular Music and Local Identity. London and New York: Leicester University Press.

(1997) "Flat city sounds: a cartography of the Christchurch music scene", Popular Music and Society 21(3): 83-105.

The Northern Star (1980) "Second Cold Chisel visit in two months", The Northern Star, January $16,27$.

Positive Timing (2008) MySpace Profile, <http://www.myspace.com/positivetiming> (accessed July 23, 2008)

Smith, Susan (2000) "Performing the (sound)world", Environment and Planning D: Society and Space, 18: 615 - 637.

Straw, Will (1991) "Systems of articulation, logics of change: communities and scenes in popular music", Cultural Studies, 5(3): 368-388.

Taylor, Timothy (1997) Global Pop: World Music, World Markets. New York: Routledge.

Tourism NSW (2008) Tourism Statistics: Travel to Northern Rivers, $<$ www.tourism.nsw.gov.au>

Turner, T (2005) 'Review of World CitiZen', CD Baby, <http://cdbaby.com/cd/yeshe>

Waitt, Gordon (1997) "Selling paradise and adventure: representations of landscape in the tourist advertising of Australia", Australian Geographical Studies, 35: 47-60.

(1999) 'Naturalizing the 'primitive': A critique of marketing Australia's indigenous people as 'hunter-gatherers"', Tourism Geographies 1(2): 142-163.

Wittel, Andreas (2001) "Towards a Network Sociality", Theory, Culture and Society, 18(6): 51-57.

Wood, Nicola, Duffy, Michelle and Smith, Susan (2007) “The art of doing (geographies of) music", Environment and Planning D: Society and Space, 25(5): 867-889.

\section{Discography}

Diana Ah Naid, Diana Ah Naid (CD, Origin, 1997) 
Diana Anaid, Live at the Bush Theatre (CD, Forola, 2007)

David Birch, Byron Journey (CD, self-released, 1997)

Troy Cassar-Daley, Big River (CD, Columbia/Sony Music, 1999)

Defect, Fridgit (CD, Oracle Distribution Service, 1997)

Grinspoon, Grinspoon (CD, Oracle Records, 1995)

Grinspoon, Alibis and Other Lies (CD, Universal Music Group, 2007)

Khaki Marquee, Khaki Marquee (Cassette, Green Tent, nd)

The Lame-Os, Who's Stupid Idea was This Tape Launch Anyway (Cassette, selfreleased, nd)

Yeshe Mbira, World CitiZen (CD, Dog My Cat Records, 2005)

Positive Timing, Positive Timing (CD, self-released, 2008)

Ragadoll, The Psychotic Dance Hall Call (CD, Rumple Records, 1998)

Seven, Seven (CD, Self-released, 1998)

The Simpletons, Matter (CD, Candle Records, 1995)

The Strap Ons, Limbo Time (7" vinyl EP, EMI Custom Records, c1985)

Soy Division, Soy Division (Cassette, Green Tent, nd)

Tarshito, Playing in the Rainbow (CD, Kittani Music, 1994)

Various Artists, Edges Are Fun (CD, Edgecore, 2002)

Very Unique Existence, Everyone (CD, Self-released, 2008) 